\title{
THE LACK OF SOCIAL WELL-BEING IN TWO DISADVANTAGED HUNGARIAN MICRO-REGIONS
}

\section{A TÁRSADALMI JÓL-LÉT HIÁNYA KÉT MAGYARORSZÁGI HÁTRÁNYOS HELYZETÜ KISTÉRSÉGBEN}

\author{
Nóra BARANYAI ${ }^{\mathrm{a}}$, Júlia SCHUCHMANN ${ }^{\mathrm{a}}$ \\ ${ }^{a}$ Kodolanyi Janos University of Applied Sciences, Institute for Regional Studies CERS HAS, Address: \\ 8000 Székesfehérvár, Fürdő u. 1, e-mail: baranyain@rkk.hu; e-mail: schuchmann@kodolanyi.hu
}

Cite this article: Baranyai, N., Schuchmann, J. (2015). The Lack of Social Well-Being in Two Disadvantaged Hungarian Micro-Regions. Deturope, 7, 2: 258-274

\begin{abstract}
The main objective of this paper is to reveal the crucial economic and social factors determining the lack of social well-being in two disadvantaged micro-regions of different geographical locations in Hungary, and to summarize the similarities and differences between them. The study also compares the two analysed cases in terms of subjective well-being, as well as indicators of micro-regions and urban areas located in the same county in order to demonstrate the inter- and intraregional differences. According to the hypothesis, basically the east-west determined spatial inequalities of objective social well-being emerge also in connection with subjective well-being issues. The results are based on an empirical research using qualitative and quantitative methods conducted in 2014.
\end{abstract}

Key words: social well-being, disadvantaged micro-regions, inner and outer peripheries

\begin{abstract}
Absztrakt
A tanulmány célja, hogy megvizsgálja a társadalmi jól-lét hiányát okozó gazdasági és társadalmi tényezőket két eltérő földrajzi elhelyezkedésű hátrányos helyzetü kistérségben, s hogy összegezze a közöttük meglévő hasonlóságokat, különbségeket. A tanulmány összeveti a kistérségek vizsgált folyamatait egyfelől egymással, másfelől pedig az azonos megyében lévő vidéki nagyváros-térségek hasonló mutatóival, s feltárja a társadalmi szubjektív jól-lét inter- és intraregionális különbségeit. A tanulmány feltevése az, hogy az objektív társadalmi jól-lét alapvetően nyugat-kelet meghatározottságú területi különbségei a szubjektív jól-lét tekintetében is megnyilvánulnak. Az eredmények egy 2014-ben lebonyolított, kvalitatív és kvantitatív módszereket is alkalmazó empirikus kutatáson alapulnak.
\end{abstract}

Kulcsszavak: társadalmi jól-lét, halmozottan hátrányos kistérségek, belső és külső perifériák

\section{INTRODUCTION}

Social well-being is a new paradigm. In 2008 the former French president Nicholas Sarkozy invited the Nobel prized economist Joseph E. Stiglitz and his outstanding colleagues to reconsider the role of the GDP (Gross Domestic Product) within the confines of competitiveness. The scientific committee lead by professor Stiglitz published the famous 
paper"Report by the commission on the Measurement of Economic Performance and Social Progress" in 2009. The report stated that one of the major causes of the current global economic crisis is the following: the GDP that an indicator to be used for measuring social and economic processes is unable to measure social development. That is why it would be necessary to introduce certain innovative measurement tools. These tools are taking into account the aspects of sustainable development, its main pillars, the economic, environmental and social contexts, including the social well-being as well (Szirmai, 2015, 11). The term of social well-being comprises eight factors: the material living conditions (such as income, consumption and wealth indicators) the aspects of health, education, personal activities (including work) as well as the indicators of political representation and governance i.e. the indicators of political advocacy, the contexts of social and personal relationships, the aspect of present and future environmental conditions and finally the dimensions of economic and physical uncertainties (Stiglitz - Sen - Fitoussi, 2009).

The analysis of social well-being is particularly important not only for the formation of regional competitiveness, also for the management of contemporary social-spatial inequalities, which are gradually increasing (Pittau - Zelli - Gelman, 2010). As a consequence of the global economic crisis, job insecurity is also growingly present in the European countries. Based on several research results, the deteriorating social disparities hinder the economic performance as well, accordingly the primary aim of governments should be to mitigate these inequalities (Rodriguez-Pose, 1998).

The resistance against the crisis was more successful in those European regions which have strong economic and social infrastructural bases, and in those which were able to form the possibilities to connect into the global economic processes. However, the negative impacts of the great recession affected more seriously the less developed regions. Regional inequalities and social polarization have been increased for example in Hungary, especially during the transition period due to the historic effects and the impacts of globalization. In addition, the various effects were appeared in large differentiations, resulted the 'winners' and 'losers' regions. (Dusek et al. 2014; Enyedi, 1996; Enyedi 2009; Horváth, 2014). The global economy generally prefers those regions where the qualified labour force concentrated and where the good accessibility, infrastructure and appropriate milieu for economic development are present. It is possible to mention certain examples in the Hungarian context: the western regions and the large urban areas, especially the Budapest Metropolitan Area are among the positive examples. The eastern - in particular rural - regions are mostly among the losers. These areas have unfavourable locations due to peripheric geographical situation and the lack 
of the good accessibility included the higher concentration of disadvantaged social groups. The results of social exclusion are apparent also throughout the disadvantaged rural areas: the urban poor are increasingly moving out to the rural areas because of the higher urban real estate prices (Kovács - Timár -Váradi, 2015).

The main objective of this paper is to reveal the main economic and social factors determining the lack of social well-being in two disadvantaged micro-regions of different geographical position in Hungary and to summarize the similarities and differences between them. The study also compares the two analysed cases in terms of subjective well-being, as well as indicators of micro-regions and urban areas located in the same county in order to demonstrate the inter- and intraregional differences. According to our hypothesis, the basically east-west determined spatial inequalities of objective social well-being emerge also in terms of subjective well-being issues.

The micro-regions of Fehérgyarmat and Sárbogárd were chosen as disadvantaged areas based on their weak social and economic indicators. The Fehérgyarmat micro-region is located in one of the least developed regions of the country bordering Ukraine and Romania. The accessibility of the Fehérgyarmat micro-region is extremely bad, because of the lack of good and fast transport connections (there is no motorway nearby). The distance from the capital city, Budapest, is $200 \mathrm{~km}$. The nearest large city is the county seat Nyíregyháza with 110,000 inhabitants.

The second examined micro-region, the Sárbogárd micro-region is also a socioeconomically disadvantaged area located in the southern part of Fejér county. The microregion is made up of ten settlements, a small town (Sárbogárd), one large (Cece) and eight small villages (Alap, Alsószentiván, Hantos, Igar, Mezőszilas, Nagylók, Sáregres, Vajta). In 201125198 person lived in the micro-region altogether, which is almost six percent of the county's population. The nearest large city is the county-seat Székesfehérvár with 100,000 inhabitants (see Fig. 1). 
Figure 1 The location of the micro-regions of Fehérgyarmat and Sárbogárd in Hungary

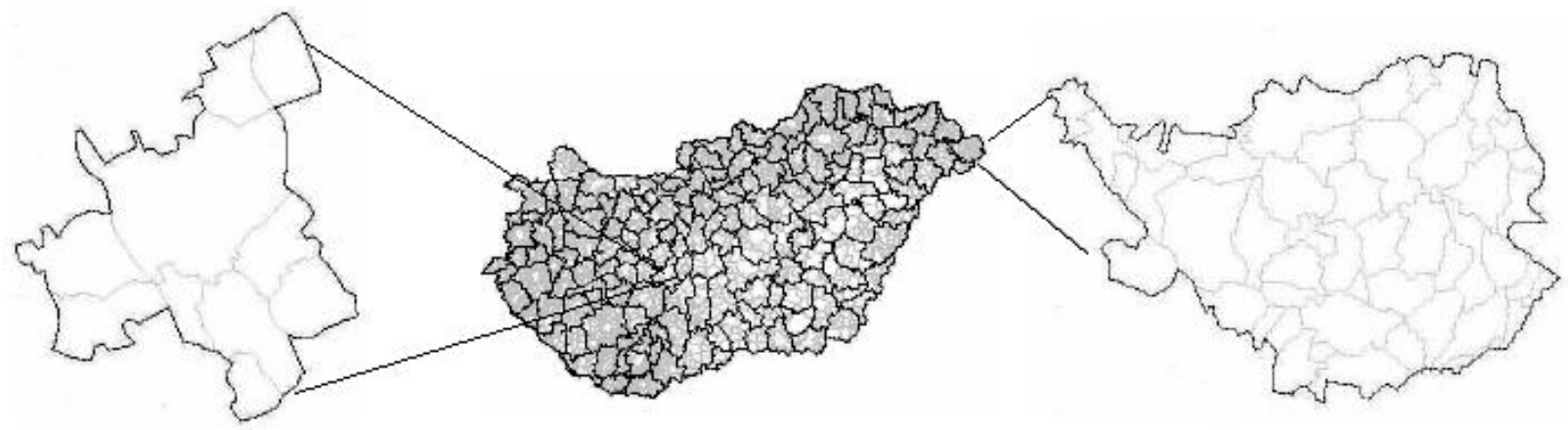

Edited by Baranyai, N. 2015

The results presented below are based on an empirical research using qualitative and quantitative methods. As a qualitative segment of analysis we conducted 30 in-depth interviews with prominent local persons in each micro-regions. In order to reveal the social well-being of people living in nine Hungarian urban $\operatorname{areas}^{83}$ and micro-regions ${ }^{84}$, two empirical surveys were conducted in 2014. The research in urban areas was based on a representative sample of 5000 people, while in micro-regions 1600 questionnaire were collected (400 in each micro-regions). Beyond general demographic questions surveys contained blocks concerning issues of employment, migration, satisfaction, confidence, happiness, success, health and household supply.

\section{The lower level of social well-being in the north-eastern border in Hungary}

The multiple disadvantaged position of the micro-region of Fehérgyarmat is explained by many reasons based on the relevant researches.

1. Firstly historical reasons: the north-eastern part of Hungary, especially SzabolcsSzatmár-Bereg County near the Ukrainian border is a historically underdeveloped region. Local economy was primarily based on agriculture and limited food production. During the period of state socialism most of the agro products (fruit, vegetables) served and depended on Soviet market. But after the 1990's the collapse of the soviet markets made the local economy very vulnerable.

2. Secondly, the lack of significant foreign investments. Since 1990 the trend has been that most multinational companies concentrated in the capital city and its region (Budapest

\footnotetext{
${ }^{83}$ Hungarian urban areas are cities with the population over 100,000 (Budapest, Debrecen, Győr, Kecskemét, Miskolc, Nyíregyháza, Pécs, Szeged, Székesfehérvár) and their agglomeration zones.

${ }^{84}$ The research was carried out in four disadvantaged micro-regions, two areas near to the eastern border (Fehérgyarmat and Sarkad micro-region) and another two regions representing the internal periphery located in Transdanubia (Sárbogárd and Sásd micro-region).
} 
Metropolitan Region) or the Transdanubian and western part of the country. The multinational capital avoided the north-eastern part of Hungary especially the regions without good transport connections and qualified workforce.

3. Thirdly, higher proportion of disadvantaged social groups. The concentration of the most vulnerable social groups is common especially in the north-eastern region in small villages beside the border.

The social and economic difficulties of this micro-region exacerbated by the negative demographic situation as well. The population has been decreasing for years, because of high mortality and massive scale migration from this region. The population of Hungary has also been decreasing for decades, but not as fast as in this multiple disadvantaged micro-region (see Fig. 2 and Fig. 3).

Figure 2 Changes of the population in the country, the region and the micro-region between 2001 and $2011, \%$

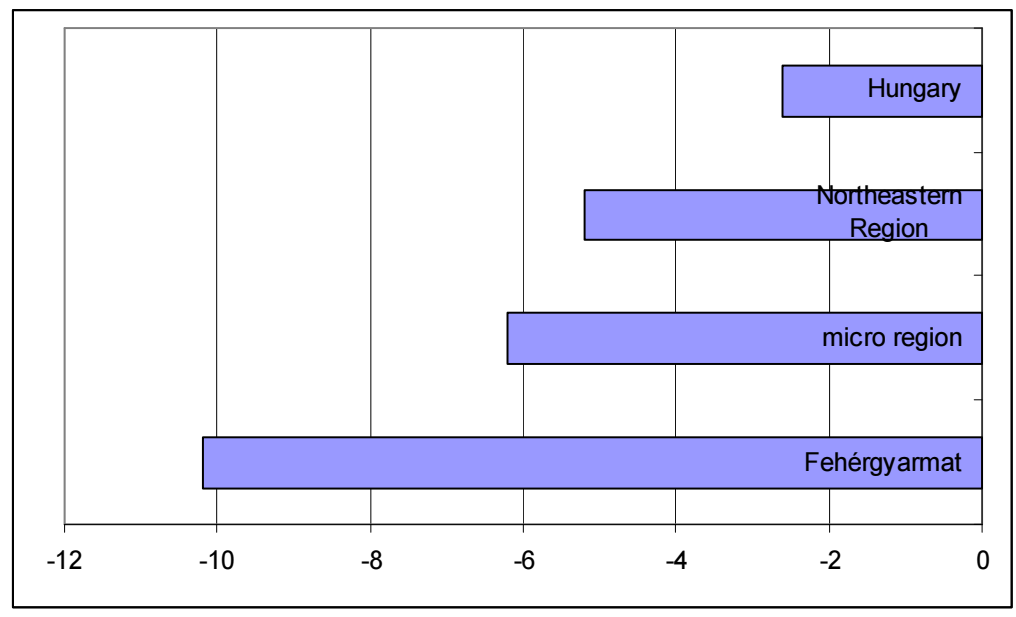

Source: Hungarian Central Statistical Office edited by Julia Schuchmann

The most important cause of the population loss is the out-migration due to the lack of job opportunities in the city and its region as well. Because of the outmigration of young active people ageing is a crucial problem as well. The average proportion of elderly people is $23 \%$, while the country average is $17 \%$.

The economic performance of this micro-region is hindered not only by the bad demographic situation (out-migration of young and educated people, ageing population) but also by the higher proportions of low educated people. In the micro-region of Fehérgyarmat the average proportion of highly educated people is only $9,2 \%$ in contrast to the country average of $19 \%$ in 2011 . As far as the multiple disadvantaged social groups are concerned: the average proportion of the roma minority in this regions is four times higher $(12 \%)$ than the 
country average which is $3 \%$. The Romany minorities are the most vulnerable social groups in terms of their accessibility to the health care system, or to education and to healthy life.

As far as concern the employment situation in the micro-region, the results are very unfavourable. During the last two decades most of the former socialist companies collapsed. The former so called „kolhoz” or collective farms collapsed as well. Actually the biggest employer is the local hospital with 400 employees, and the municipality of Fehérgyarmat with 120 employees. As mentioned already in the introduction the multinational capital is not really interested to invest in this region, because of the unfavourable geographical and social characteristics of the micro-region. The employment situation is the worst in the small villages right beside the Ukrainian border. The proportion of employees among the active population in the Fehérgyarmat micro-region is 51,2\% while in the urban areas of Nyíregyháza is $80 \%$ (see Tab. 1). After the introduction of the public work program (2013) practically this is the only possibilities to work for many people. The public work program was introduced in 2013 and it has become practically the only job opportunity for many people. The public work program is criticized very sharply in Hungary because of many reasons (it contributes to the social tensions between the mayors and local citizens, the public work program does not offer valuable job opportunities, it contributes to the exclusion from the labour market). It is now clear that public work programs cannot solve the problem of heavy unemployment in these unfavourable micro-regions they are only temporarily solution.

The local government intends to invite a Chinese investor to Fehérgyarmat. They are planning to set up an assembly factory with 300 employees. They started to negotiate, but until today without any real results.

Based on the interviews with local policy and local decision makers we can highlight four social and economic factors which hinder the development of the micro-region.

The first one is the extremely fast out-migration of the young and educated people from the micro-region. If this process continues without any changes in the future, the chances that any new industry or services will invest here. The competition between the cities (the Romanian border is near, and the city of Satu Mare with 100, 000 inhabitants is too close) in the region for prospective investors is big, and Fehérgyarmat is losing in this competition.

The second structural problem is the higher proportion of uneducated or low skilled people in the micro-region. The training programs of the local vocational school do not meet he current requirements of the global and local economy either. They train especially catering specialists, but the majority of the young people who complete the courses do not find any job opportunities in the micro-region. The development in tourism is quite moderate, there are 
only few restaurants. In the city there is only one accommodation possibility. At the same time the local small and medium sized enterprises cannot find available skilled workers.

The third problem is the lack of any long term development strategy which suits the real social and economic conditions of the micro-region. Local government prefers to invite multinational companies to settle down in the micro-region but without having available local skilled workers.

The fourth problem is the generally low motivation of local people to change their negative attitudes. The problem is that most of the local people feel as a victims of the transition period, and many of them are waiting passively for help (from the EU, the central government, the municipality, etc.) to get a job or to have a better life.

These four negative factors reinforce each other and create a "vicious circle" and hinder the well- being of local inhabitants. So the biggest challenge for the decision makers is to help the micro-region to gradually get out of this negative spiral.

\section{Inner periphery: the micro-region of Sárbogárd}

\section{The determinant factors of the region's disadvantaged position}

The territory of the micro-region belongs to a good quality agricultural land called Mezőföld, hence crop growing and stock-raising became typical activities in the area. Light and heavy industry firms in regional and surrounding towns offered another possibility for employment. After the transition collective farms split up, but surrounding firms were still able to absorb labour force. Soon these firms also started to decline resulting in significant unemployment in the micro-region. The withdrawal of foreign investments also affected the micro-region, when Mannesmann relocated its manufacturing unit from Sárbogárd to China in 2000. In the same year local troops of the Hungarian Army were eliminated. Subsequently the last major employers left the area leaving behind a significant number of supplier enterprises without work and future. Afterwards only the settled transnational companies in economic centres (Székesfehérvár, Dunaújváros) and a few smaller firms offered jobs for the area's workingage population, which notably altered the direction, the intensity and the duration of commuting. Nowadays agriculture is characterised by large-scale farming, accordingly, due to mechanization, living labour became in general redundant. The manufacturing sector remained weak, the firms turn out products of low added value. Due to the infrastructural developments of recent years the micro-region's transport network is eligible, even so the area is not attractive for investors. Although the micro-region is rich in natural values, the additional costs of environmental protection that burden the prospective investors hinder 
economic development. On the other hand, tourism has a significant, albeit unexploited potential. Based on these characteristics, as well as the related statistical indicators, the microregion - together with the neighbouring Enying micro-region - constitutes the county's socially and economically disadvantaged inner periphery, and also in terms of employment and infrastructure. The micro-region has decreasing and ageing population, partly caused by low birth rates, which are not able to equalize deaths, partly by the migration of young, qualified or job seeking lower qualified people (see Fig. 3). The majority of the population, especially the former agricultural workers, are unskilled, which inhibits employment, and causes long-term unemployment in the micro-region. Additionally, due to the fragmented structure of the settlement, Sárbogárd is a wide, rustic town with a lack of urban, therefore subregional functions (employment, education).

\section{Processes and problems in terms of well-being dimensions}

As we have already mentioned above, the employment opportunities are quite limited in the micro-region. Due to the lack of large and medium sized enterprises labour market is very narrow in the centre of the micro-region, accordingly the majority of working-age population can find jobs neither in Sárbogárd, nor in the nearby small towns (Simontornya, Enying). However, they have the chance to find employment at transnational companies in economic centres (mainly in Székesfehérvár or Dunaújváros) and in distant cities (Paks, Szekszárd), where they work mostly in three or continuous shifts. Workers are by necessity daily commuters; fortunately most of the companies still ensure transport between the habitation and workplace by contractual bus services. We mentioned 'still', because as a result of global financial and economic crisis, companies primarily dismissed employees who live far from their workplace, and reduced delivery zone to 40 kilometres. Currently it is rumoured that these zones will be further narrowed, which can lead to a subsequent high unemployment in the micro-region's southern small villages. 
Figure 3 Vital statistics in the Fehérgyarmat and Sárbogárd micro-regions, 1980 - 2011, (person)

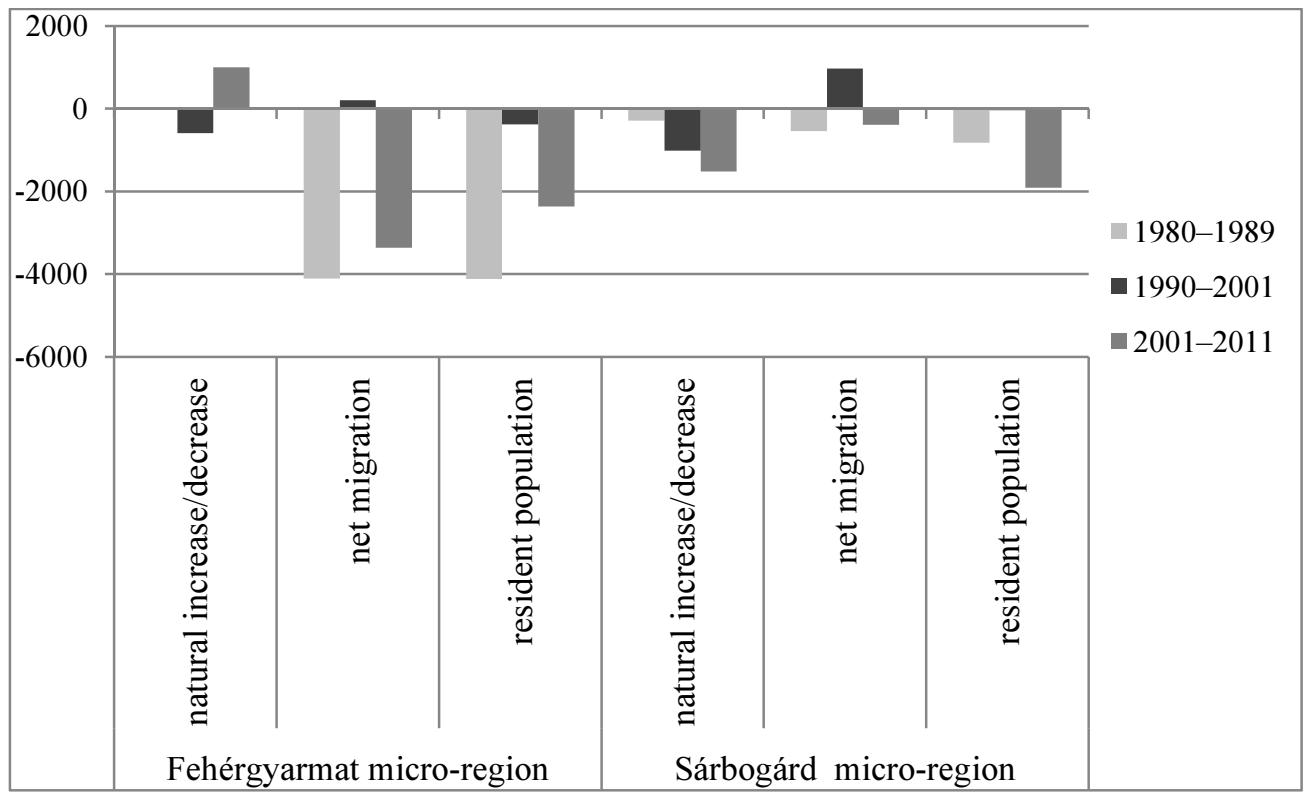

Source: Hungarian Central Statistical Office

At the level of settlements local governments or mayor's offices became the largest employers by occupying civil and public servants in local institutions, as well as masses of public workers in recent years. Considering the labour needs of regional companies, the distribution of job status is not surprising. Most of the employed are semi-skilled workers $(46 \%)$ or skilled workers $(19.5 \%)$ in the micro-region (the average proportion is $26.7 \%$ and $24 \%$ in micro-regions; $20.1 \%$ and $26.1 \%$ in the industrialized Székesfehérvár urban area), while white-collar positions are almost non-existent (KJU 2014, HAS CERS 2014). Employment characteristics naturally leave marks on the population's living conditions. The level of infrastructural facilities and public utilities of households remain well below the county values. The proportion of dwellings with full comfort is more than $20 \%$ lower than the county average $(67.1 \%)$ and the ratio of low comfort level houses (semi-comfort, without comfort) is $17.5 \%$ ( $7 \%$ in the county). There are also deficiencies in communal supply, especially in the field of public sewerage network. The proportion of dwellings connected to sewerage network is only $43.8 \%$ in the micro-region (77.6\% in the county), but we must note, that significant intra-micro-regional differences can be observed: in seven settlements the network is entirely absent (KSH 2011).

In the field of health services the future of the general practitioners service seems to be uncertain. The signs of future problems are visible right now, as physicians are ageing and some of the positions are already unfilled (in such cases replacement from neighbouring settlements is a common practice). This problem is basically caused by the low financing of 
practices ${ }^{85}$ and the low income of general practitioners. The institutional network is sufficient due to specialist's consultations and outpatient services in Sárbogárd, Enying and to the hospital in Székesfehérvár. There are more serious problems with the level of supply (emigration of physicians, waiting lists etc.), however, it is rather a national than a regional, micro-regional issue. Due to the low number of children there is no need or reason to maintain primary schools in every village, albeit local governments generally stand upon to preserve them (or at least the first four grades) in order to ensure attachment to the settlements. However, local governments heaved a sigh of relief when educational institutions were moved under state maintenance in 2013, although in many cases they do not agree with the operation and spirit of the Klebelsberg Institution Management Centre (KLIK). Due to the lack of some special education teachers, professionals dealing with children with special educational needs are overburdened. Governmental intervention is needed in this area, because the number of disadvantaged and SEN-children (special educational needs) is still growing. The only secondary school in Sárbogárd is a grammar school with 4 and 8 grades $^{86}$, thus there is a complete lack of vocational institutions. Accordingly, young people must also commute to Székesfehérvár, Dunaújváros, Simontornya, Szekszárd, if they want to learn a trade. Political and civic activity is definitely low in the micro-region. The participation of the inhabitants in parliamentary, local and EU elections was significantly lower in the last decade than in the county (OVB 2009, 2010, 2014), however, based on our empirical data the main political events (i.e. elections) are almost completely known, contrary to the alternative participation opportunities (for example referendum, public forum, demonstration). Due to the small number of civil or non-governmental organizations and their dependency on local governments, real civil activity is weak in the micro-region. Successful community building depends on several factors, inter alia on the structure and the size of the settlement, the existence and quality of public spaces, and - mainly - on the personality of the facilitator (mayor, cultural manager etc.). Environmental and security issues are both related to traffic. Based on the settlements' transport-geographical positions, significant internal differences can be observed in the micro-region. In the southern, underdeveloped part of the area high level of traffic (in many cases trucks) causes problems in the fields of air and noise pollution, safety, which make the inhabitants' quality of life worse. In terms of safety the advanced transportgeographical position appears rather as a disadvantage, since the easy access and lots of

\footnotetext{
${ }^{85}$ From January 2015 all the practices got monthly 130 thousand forints more governmental support in order to raise the level of service and to make the profession attractive.

${ }^{86}$ Previously it was a grammar and vocational school, and adapted the vocational structure to the needs of local companies.
} 
escape directions are favourable for transit crime. Accordingly, in the northern part of the micro-region, particularly in the isolated settlements crimes are rarer.

Reviewing the micro-region's problems along well-being factors, economic and social deficits are unequivocal. Interestingly, these problems have been well known for decades, as it emerges from assessments and development plans. Development aims slightly changed, suggesting that programs died away or were not sufficiently developed and financed in order to stimulate the micro-region.

\section{The spatial differences of objective well-being indicators}

Notwithstanding that the two micro-regions have different past and started from different position after the transition, the experienced trends in social and economic processes are rather similar. Although migration processes and employment opportunities are undoubtedly better in the Sárbogárd micro-region, it does not provide a long-term vision for the area. The investment promotion policy of local governments in the last decades can be evaluated as a defeat. The failure cannot be explained by only the structural and functional deficiencies of micro-regions. As it is widely known, companies prefer to settle down in larger cities, hence there are suitable conditions for production (infrastructure, labour, tax relief). The small and medium-sized enterprises - suffering from lack of capital and resources - could and cannot solve the employment problems alone in the micro-regions. What is the way forward? For the basically agricultural micro-regions the change in agricultural priorities can be a possible (and partial) solution. Changeover to more labour-demanding smaller investments can lead to wider employment in this economic sector.

Table 1 Labour market position of working-age population, 2014 (\%)

\begin{tabular}{c|ccc}
\hline Regions & Employed & Public worker & Unemployed \\
\hline Fehérgyarmat micro-region & 51,2 & 32,5 & 15,9 \\
Sárbogárd micro-region & 62,6 & 9,8 & 27,7 \\
average of micro-regions & 51,9 & 21,8 & 26,5 \\
Nyíregyháza urban area & 80,2 & 3,5 & 16,4 \\
Székesfehérvár urban area & 84,3 & 2,5 & 13,2 \\
average of urban areas & 80,2 & 3,5 & 16,4
\end{tabular}

Source: KJU and HAS CERS

The other way of expanding employment is the public work program initiated and supported by the central government. Local governments welcomed the increased headcount and resources within the framework of the program, as they can purchase assets, equipment, 
and manage the settlement's operational tasks, renewals etc. On the level of individuals public work is an obligate solution, particularly in the case of non-skilled people. Contrary to governmental goals, in these micro-regions public work is not a transitory station between inactivity and employment in the labour market, it rather seems to be a stable position, and 'will provide job opportunities for most people also in the future'. In several cases the needy and eligible mass is wider than the number of public work positions. In these cases local governments/mayors have to decide who to employ, which can lead to conflicts or abuses. However, occasionally public work is just a 30-day program, with the only aim to become eligible for social support in the following year.

The labour market position of the working-age population in the Sárbogárd micro-region is more favourable comparing to the other examined micro-regions (see Tab. 2). Most of them is employed full or part-time, although unemployment is a bit higher than the average, with narrower strata of public workers. If we consider the data of the nearest urban area, the employment gap is unequivocal. Székesfehérvár concentrates a lot of job opportunities, the rate of employment is much higher than in the micro-region (moreover, higher than the average of urban areas) with a smaller number of unemployed people and public workers.

As an indicator of living standard we analysed payment problems related to households' fix expenditures (maintenance of dwellings, i.e. electricity, gas). Due to the higher employment rate and related incomes the Sárbogárd micro-region's population has fewer problems with payment than the residents of the Fehérgyarmat area and the average (see Tab. 3). Moreover, while on a par $7.8 \%$ of the population were excluded from some public utilities due to arrears of pay in the micro-regions, this ratio in the Sárbogárd area is only $1.6 \%$. The financial situation of the respondents is a good indicator of social problems in the analysed disadvantaged micro-regions. The majority of the population in the Fehérgyarmat microregion lives on the edge of the poverty line, and they only earn the minimum wage. It means $30,2 \%$ of the respondents have monthly problems to pay the overhead expenses. This average in the urban area of Nyíregyháza is only 6,5\%. Surprisingly, the population of the Székesfehérvár urban area has more serious problems with the payment than the others, moreover, among them the monthly troubles are more often than in the Sárbogárd microregion. 
Table 2 Payment problems related to households' fix expenditures, 2014 (\%)

\begin{tabular}{|c|c|c|c|c|c|c|}
\hline $\begin{array}{l}\text { The costs of } \\
\text { maintenance }\end{array}$ & $\begin{array}{l}\text { Fehérgyarmat } \\
\text { micro- region }\end{array}$ & $\begin{array}{l}\text { Sárbogárd } \\
\text { micro- } \\
\text { region }\end{array}$ & $\begin{array}{c}\text { Average of } \\
\text { micro- } \\
\text { regions }\end{array}$ & $\begin{array}{l}\text { Nyíregyháza } \\
\text { urban area }\end{array}$ & $\begin{array}{c}\text { Székesfehérvár } \\
\text { urban area }\end{array}$ & $\begin{array}{l}\text { Average of } \\
\text { urban areas }\end{array}$ \\
\hline Causes no problem & 35,1 & 55,8 & 42,7 & 76,3 & 60,9 & 55,7 \\
\hline Sometimes problem & 31,8 & 29,4 & 30,4 & 16,1 & 23,8 & 27,1 \\
\hline $\begin{array}{l}\text { Problem month by } \\
\text { month }\end{array}$ & 30,2 & 11,8 & 24,0 & 6,5 & 15,3 & 14,4 \\
\hline $\begin{array}{l}\text { Already unable to } \\
\text { pay }\end{array}$ & 2,7 & 3,0 & 2,8 & 0,4 & 0,0 & 1,2 \\
\hline $\begin{array}{c}\text { Do not have such } \\
\text { cost }\end{array}$ & 0,0 & 0,0 & 0,1 & 0,0 & 0,0 & 0,0 \\
\hline Do not know & 0,0 & 0,0 & 0,1 & 0,0 & 0,0 & 1,6 \\
\hline
\end{tabular}

The insecurity of jobs is a crucial problem in the analysed disadvantaged micro-regions. The level of fear of becoming unemployed is significantly higher among public workers, which seem to confirm the insecurity of this employment type and the defencelessness of people. The employed persons feel themselves relatively in safe, however, in micro-regions the fear from unemployment is unequivocally stronger, which can be explained with fewer alternative employment opportunities in these areas (see Fig. 4).

Figure 4 The fear of becoming unemployed, 2014 (average value)

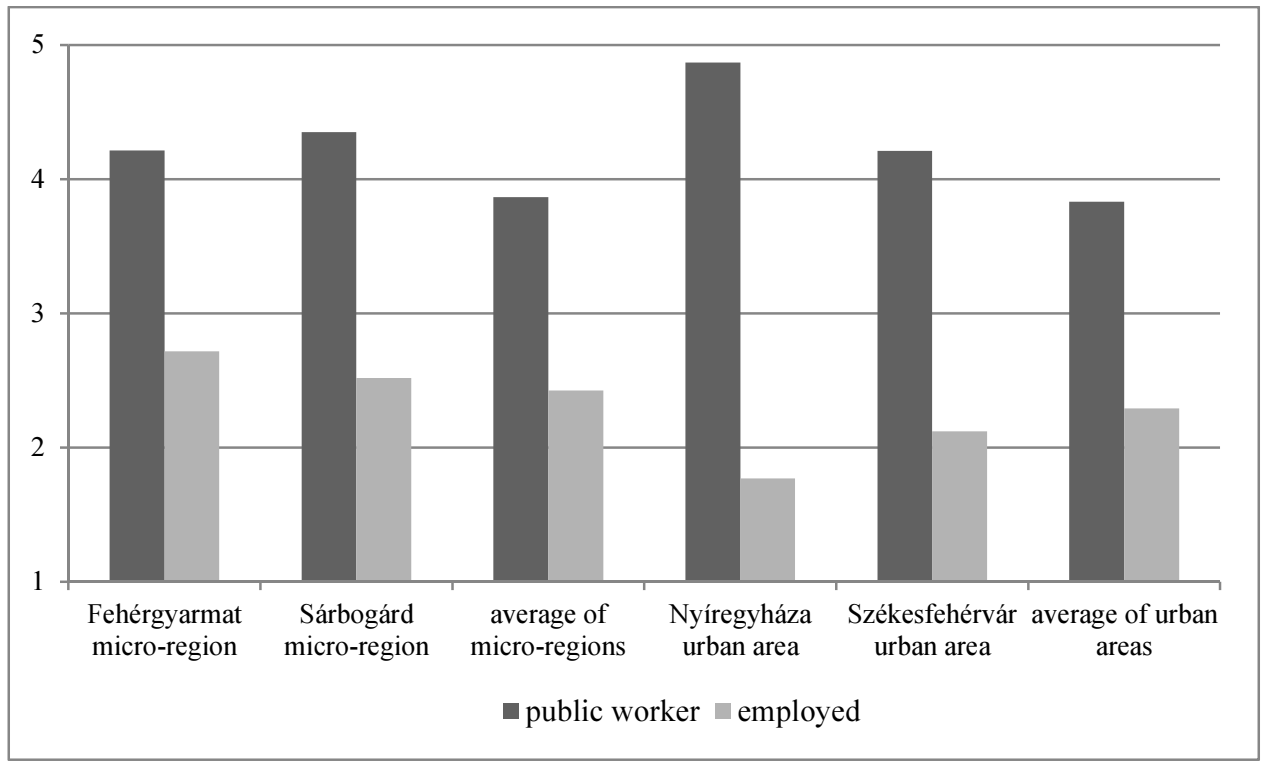

Source: KJU and HAS CERS

Note: values may vary from 1 to $5(1=$ not afraid at all, $5=$ very afraid $)$

Consequently, considering the social problems of the inhabitants, local governments need to build a strong social safety net, and to organize several services in order to facilitate the lives of the increasingly aging local communities (e.g. travel, shopping, medical attendance). 
These expenditures largely encumber local budgets ${ }^{87}$, and necessarily postpone other renewals and developments (infrastructure, services, built environment). On the other hand, unfavourable economic situation also has an effect on the individuals' mentality and their level of subjective well-being. Disappointment, mistrust, lack of motivation can be experienced in the communities, "unfortunately, we also have a growing number of...I do not know, how science might classify them... resigned people”. These people do not want to become public workers; they are content with receiving social benefits or relief. Accordingly, in such cases the creation of jobs cannot be a solution in itself, but should be supplemented with social psychotherapy programs.

To avoid the further social and economic decline of the two analysed disadvantaged microregions, both local governments has to define a long term development strategy for the microregions, which includes the strategy to develop local economic and social conditions. Based on the experiences of the last decades waiting for multinational capital was quite uncertain in the case of the Sárbogárd micro-region or even unsuccessful in the case of Fehérgyarmat micro-region. They have to find a new way of development probably by more efficient utilization of the local endowments and capabilities.

\section{The subjective well-being in the micro-regions}

Above we analysed the inequalities of objective well-being issues of the Sárbogárd and Fehérgyarmat micro-regions. Based on the survey results we can also interpret the subjective well-being indicators, the happiness and life satisfaction of the inhabitants in our sample areas. Do the above stated inequalities, objective deficits appear in the individual's mind and opinion? As it can be seen in Figure 5, differences of well-being between urban areas and micro-regions are perceived, inhabitants of micro-regions feel unhappier and less satisfied than in the urban areas of the respective county. Interestingly, the happiness and satisfaction level of inhabitants in the western, more developed Fejér county is demonstrably lower than in the traditionally underdeveloped Szabolcs-Szatmár-Bereg county. As a reason for this contradictory phenomenon we assume, that the disadvantageous processes of the last few years (due to the economic crisis) had direct and deep effects on individuals' lives in developed areas (for example loss of jobs), while the eastern local societies were not affected to such an extent by the crisis, and they are already accustomed to worse circumstances.

\footnotetext{
${ }^{87}$ Although the system of social benefits changed from 1st March 2015, as districts took over several competences from local governments.
} 
Figure 5 Happiness and life satisfaction, 2014 (average value)

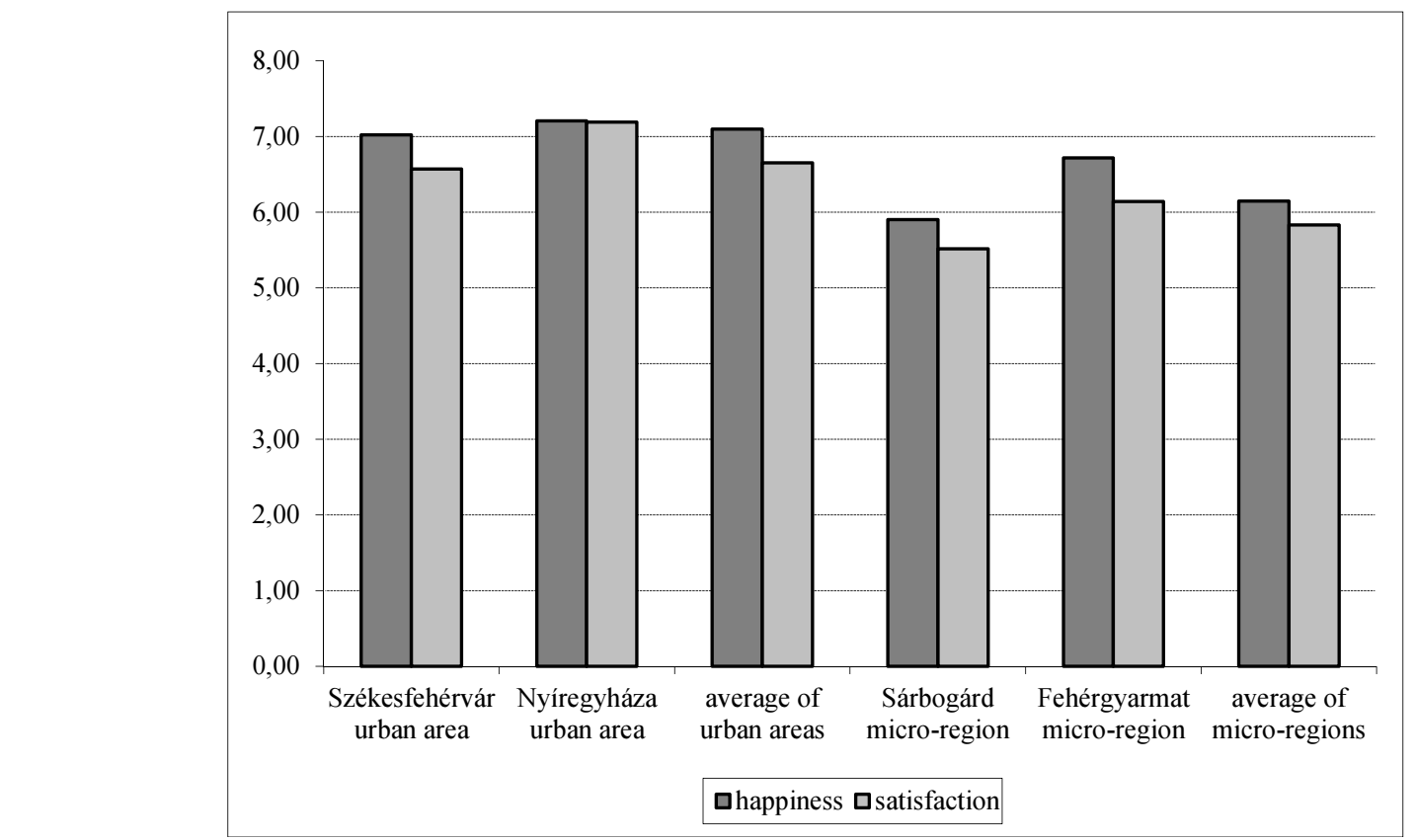

Source: KJU and HAS CERS

Note: values may vary from 0 to $10(0=$ very unhappy, $10=$ very happy)

\section{CONCLUSIONS}

The aims of this study were to analyse certain disadvantaged micro-regions, and examine the well-being issues. As well as to compare two micro regions which have different regional, social and economic position to reveal the similarities and differences between them. Based on the results of our analysis we can conclude the following:

1. The more developed micro-region has better geographical position in terms of job opportunities, and access to work. Despite the limited job possibilities in the Sárbogárd micro-region, local people can commute to the nearest large urban centres (Székesfehérvár or Dunaújváros). The distance is manageable, and these urban centres have quite strong economy. Many companies from the surrounding areas still ensure transport between the habitation and workplace of their employees by contractual bus services. The better geographical position of the Sárbogárd micro-region is reflected in the level of well-being in terms of objective well-being indicators, which are a little better than those in the Fehérgyarmat micro-region.

2. The less developed Fehérgyarmat micro-region has a very unfavourable geographical position. There are only a few job possibilities not only in the micro-region but in the surrounding areas as well. The local workers have no real means to commute; they are literally stuck in the micro-region. Contrary to the Sárbogárd micro-region, in the 
Fehérgyarmat micro-region there are no companies and enterprises that employ significant workforce. The high costs of commuting are place too much financial burden on for the majority of the local people.

3. On the other hand, the two micro regions have similar characteristics in terms of their local economic development concepts. Both analysed micro-regions based their local development on multinational companies. But this strategy seemed to be quite uncertain, and strengthened their economic dependence on external conditions. In the case of Sárbogárd this strategy proved to be quite unsuccessful when Mannesmann relocated their production to China. In the case of the Fehérgyarmat micro-region there are no multinational companies that showed serious interest in settling down.

4. Both micro-regions have strong historical, agricultural endowment and knowledge, but they have been unexploited for decades. For the future they should define new ways of local economic development which will be better suited to the local endowments and possibilities.

5. Based on the empirical analyses, the basic statements of the study were confirmed in the following aspects: firstly, the objective well-being indicators were basically higher in the urban areas than in the rural areas. Secondly, the objective well-being indicators - the labour market position and the general living standards - were better in the Sárbogárd micro-region than in the other rural areas. But, contrary to our hypothesis, the indicators of subjective well-being were more developed in Fehérgyarmat microregion, because of the greater satisfaction of inhabitants. According to the facts, in the underdeveloped Fehérgyarmat micro-region people were more satisfied with their life conditions, they were happier than in the economically more developed Sárbogárd micro-region. To summarise these statements: the objective and the subjective wellbeing indicators manifested in the certain regions are not necessarily related to each other.

\section{REFERENCES}

Dusek, T. - Lukács, R. - Rácz, I. (2014): Development differences among the Regions of Hungary. Procedia Economics and Finance, Vol. 9. pp. 264-277.

Enyedi, Gy. (1996): Regionális folyamatok Magyarországon az átmenet időszakában (Regional Processes in Hungary in the Period of Transition). Budapest, Hilscher Rezső Szociálpolitikai Egyesület.

Enyedi, Gy. (2009): Competitiveness of the Hungarian Regions Hungarian Geographical Bulletin, Vol.58. pp. 33-48. 
Horváth, Gy. (2014): A decentralizáció hasznáról (On the utility of decentralization). In Berki, M. - Halász, L. (szerk.): A társadalom terei, a tér társadalma (pp. 25-39). Budapest, Art Webber Studió.

Kovács, K - Bihari, Zs. (2005): Slopes and Slides: Spatial Inequalities in Employment Opportunities at the Turn of the Millennium. In: Barta, Gy. - G. Fekete, É. - Szörényiné Kukorelli, I. - Timár, J. (eds.): Hungarian Spaces and Places: Patterns of Transition (pp. 360-377). Pécs, Centre for Regional Studies.

Kovács, K. (2008): Kistelepülések lépéskényszerben (Small Settlements Forced to Develop) In: Váradi, M. (szerk.): Kistelepülések lépéskényszerben (pp. 7-28). Budapest, Új Mandátum Kiadó.

Kovács, K. - Timár, J. - Váradi M. (2015): Well-being Deficits in Disadvantaged Regions. In Szirmai, V. (ed.): From spatial inequalities to social well-being (pp. 129-144). Székesfehérvár, Kodolányi János University of Applied Sciences.

Pittau, M.G. - Zelli, R. - Gelman, A. (2010): Economic disparities and life satisfaction in European Regions. Social Indicators Research. Vol. 96, Issue 2. pp 339-361.

Rodríguez-Pose, A. (1998): Social Conditions and Economic Performance: The Bond Between Social Structure and Regional Growth in Western Europe. International Journal of Urban and Regional Research, 22. pp. 443-459.

Stiglitz, J. E. - Sen, A. - Fitoussi, J.P. (2009): Report by the commission on the measurement of Economic Performance and Social Progress. Paris, Commission on the Measurement of Economic Performance and Social Progress.

Szirmai, V. (2015): The history of researching "Social Well-being" in Hungary. In Szirmai, V. (ed.): From spatial inequalities to social well-being (pp. 11-16). Székesfehérvár, Kodolányi János University of Applied Sciences. 